Indonesian Journal of Medicine (2017), 2(3): 146-153

https://doi.org/10.26911/theijmed.2017.02.03.01

\title{
Epithelial Rate Difference on Donor Wound of Split Thickness Skin Graft in the Thigh Area by Applying Leukocrepe $\AA$ and Medicrepe $\AA$
}

\author{
Ivan Rinaldi'), Amru Sungkar²), Untung Alifianto3) \\ 1) Public Surgery Resident of Medical Faculty at UNS \\ ${ }^{2)}$ Sub-Plastic Surgery Department at RSUD Dr. Moewardi, Surakarta \\ ${ }^{3)}$ SMF of Neurosurgery Department at RSUD Dr. Moewardi, Surakarta
}

\begin{abstract}
Background: applying split thickness graft (STSG) is as one of the reconstruction techniques and it is often conducted. Applying the technique creates superficial wound on the donor wound or it is known by donor site. The elastic bandage usage is one of the tools which is used in giving treatment to donor site as a standard operational procedure treatment at Dr. Moewardi hospital (RSDM) Surakarta. RSDM Surakarta has not had clinic test yet to compare between applying elastic bandage Leukocrepe $\AA$ and Medicrepe $\AA$ on wound care STSG on the thigh area.

Subject and Method: The study used post-test only control group design with the total of the sample was 18 patients. The study was conducted in intermediate STSG donor wound with 0.018 inches thickness on the lateral thighs. By dividing two donor wounds, a half-sided of upper part was bandaged by applying Leukocrepe $\mathbb{R}$ and the other half of the lower part was bandaged by Medicrepe®. After that, epithelialization score was conducted on the seventh day. All the data then were collected and after that the data were tested by applying Wilcoxon rank test.

Result: according to the study conducted to 18 patients of plastic surgery section at RSUD Dr. Moewardi during November 2016-Juni 2017, the result showed that the epithelialization chart was approximately $61.39 \pm 30.05 \%$ for STSG donor wound on the lateral thighs part and it was done on the seventh day by applying Leukocrepe, meanwhile applying Medicrepe, the result was

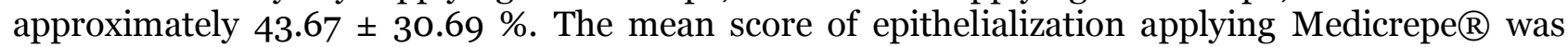
more significant than applying Leukocrepe $\AA$ and it showed that there was significantly different statistically with the score $(\mathrm{p}<0.001)$.

Conclusion: According to the result above, it can be seen that the STSG donor wound care on the

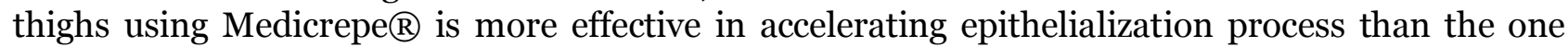
which is applied by Leukocrepe $\AA$.
\end{abstract}

Key Word: Epithelization, Elastic Bandage, Medicrepe $®$, Leukocrepe $®$

\section{Correspondence:}

Ivan Rinaldi. Public Surgery Resident of Medical Faculty of UNS. Email: ivanmudfin@gmail.com.

\section{BACKGROUND}

Applying split thickness graft (STSG) is as one of the reconstruction techniques and it is often conducted. This technique takes all the epidermis and a half of dermis as a graft source, so it creates superficial wound on the donor wound or it is known as donor site (Wiechula, 2011).
Bandaging process must be handled right after the end of a surgery process. The ideal bandage on the donor area must support quick re-epithelialization, not cause pain, need slightly care, not too expensive. The usage of the elastic bandage on the donor site has a purpose that is to get the compression effect for wound, so it can control the edema, exudate production, 
and hemostasis pressure. Therefore, those things may help the accelerating of reepithelialization wound process (Beldon, 2007).

Leukocrepe $\AA$ is non-adhesive elastic bandage typically short stretch bandage or light support which is produced by BSN medical. The elastic bandage is made of $100 \%$ cotton. This bandage can be utilized to skin graft treatment case, donor site wound treatment, varicose veins handling, secondary bandage after moist wound dressing, and for the sprain case and strain (BSN medical, 2016)

Medicrepe $\AA$ is non-adhesive elastic bandage typically long stretch bandage. It is made of mixture material which is $50 \%$ of cotton, $41 \%$ of polyamide, and $9 \%$ of polyurethrane. The bandage is generally utilized in some cases such as sprain, strain, and in some cases of compression treatment (OneMed, 2016).

The usage of elastic bandage is as one of tools used in giving treatment to donor site as a standard operational procedure treatment at Dr. Moewardi hospital Surakarta. Dr. Moewardi hospital has not had the clinic test yet which can be used to compare between STSG wound donor treatment on the thighs area and using elastic bandage differently.

\section{STSG Wound Donor (Donor Site)}

STSG wound donor (donor site) is secondary wound to get skin for having been graft. A surgeon has donor location which is classified by color, turgor, skin texture, how many grafts needed, and hidden location selection. A surgeon targets the donor location according to the color similarity, turgor, skin texture, graft needed, and hidden location targeting. Patients must understand that the primary wound is the effect of donor site which means that treatment will leave some scars on donor site. Donor site wound will cause more uncomfortable condition than the primary wound itself of being exposed nerve ending (Beldon, 2007).

The bandage process must be handled quickly right after the end of the surgery. The use of bandage after hemostasis is attained by taking wet gauze which contains epinephrine substance. The proportional bandage on the donor area must support a quick re-epithelialization, not cause pain, lightly care, and have infected low level. The use of elastic bandages causes compression in the donor wound. One of its aims is to maintaining a primary bandage, and compressing an exudate resulting from donor wound. The elastic bandage might be usually endured within 24-48 hours (Bhagwat et al., 2001; Yefta et al., 2008; Istiqomah, 2010, Wiechula, 2001).

Epithelialization is a migration process of epithelial cell from the area around of hair follicles to wound area. The epithelialization showed curing process of the wound itself. Epithelialization showed a cured process of the wound. The epithelialization of wound showed the recovery process. For the full-thickness wound, it is cured from the edge part and the epithelium could migrate around $1 \mathrm{~cm}$ before it stops and reach the wound's edge. In the contrary, partial thickness wound which is hair follicles, sweat gland, and sebaceous gland on bed wound. (Hellman, 2014).

Epithelialization brings the function back from epidermis, such as substance maintenance, temperature controlling and microbe preventing or invasitoksin. The epithelialization could also represent an important transition on wound inflammation. Many proofs showed the epidermaldermal interaction to organize skin morphogenic process, such as (skin development and wound recovery. As the epi- 
dermis responds to mediator-derived mesenchyme, keratinocytes is activated to drum the epidermal up which can secrete cytokines and growth factor to promote dermal inflammation. After cell contact is achieved by complete wound epithelialization, the release of inflammatory mediators could stop (Hellman, 2014).

There are many ways to detect epithelialization on the wound such as camera digital usage, histological assessment, or else using a simple tool which is made of mosquito netting by adjusting the size as the tulle's size. (Hatice, 2010; Bloemen, 2012; Kresna;2016)

Donor area of STSG could recover spontaneously from remaining epithelial cell from the epithelial appendices in the dermis layer or wound edge. Recovery is started within 24 hours after graft removal. The average healing process corresponds to the number of remaining epithelial appendices and it is contrast to the thickness of the graft taken. Epidermal layer could regenerate and be as a donor area, yet every graft removal which is on the dermis could not have regeneration. Epithelial growth in the early process of the regeneration is very soft and breakable by bandage movement. Hyperpigmentation is still obtained during a few months following the healing of donor area and dark-skinned individual has hypertrophic skeletal tendency on its side (Bhagwat et al, 2001; Yefta et al, 2008; Istiqomah, 2010).

Donor site recovery occurs through the re-epithelialization process. Epithelial cells migrate from epithelial seeds from reticular layer which remains in the reticular layer of dermis (hair follicles, sebaceous glands, sudoriferous glands), it was spread among wounds until the skin was totally cured and intact. This process happens during 7-10 days; however it could be longer up to 21 days, depending on age, patients' nutrition. In the first day within $3^{-}$ 4 days, donor site produces exudate, depending on how big the wound is which means the longer it is the more decreased the re-epithelialization process is. Pain level can be a measurement to measure reepithelialization process, which the nerve endings are covered by epithelial cells. Therefore, the pain will be reduced or even disappear (Beldon, 2007).

Donor wound site recovery is divided into two phases; they are wet phase and dry phase. Wet phase happens when it produces a lot of exudates, kinds of absorbent like alginate or hydrofibre which can be utilized to absorb over exudate. Wet phase occurs when exudate is produced in large quantities, a variety of absorbent such as alginate or hydrofibre can absorb excess of exudate. Dry phase is the condition which is the number of exudate drastically decreased. The indication of the wounds have been cured by applying re-epithelialization is that wound is dried, pink-colored, and itchy (Beldon, 2007).

The donor site of comprehensive wound treatment was once stated by Fowler and Dempsey (1998), suggesting to: (Beldon, 2007)

a. Giving analgetic regularly

b. Controlling pain by evaluating and immobilizing the donor

c. Observing and giving treatment toward bleeding symptom and pain caused by unrecovered infection by giving analgetic and fever medicine.

d. Rechecking the donor wound from smelling wound.

e. Assuring a good bandage for the patients

f. Letting the primary wound having contact with the bandage spontaneously.

\section{Elastic Bandage}

Elastic bandage is one of the bandages made of stretched material and it is usually used to bandaged a wound of the body. This 
type is also used to maintain bandage, fixation, make pressure, narrow movement, or control edema on the extremities. (Pierson, 2009).

The elastic bandage' shape is a roller bandage (Roller bandage), and various material used such as antara lain, cattoon, polyester, polyamide, polyurethrane and elastomeric material and so on. In its development, the raw material is almost all hypoallergenic and the rubber's percentage has small portion, so it is comfortable for the patients (Pierson, 2009; Bindl, 2011).

\section{Types of Elastic Bandage}

There are two kinds of bandage which are elastic bandage or extensible and inelastic bandage. A compression elastic bandage is usually applied for leg venous ulcers treatment by giving compression bandage treatment. Each of elastic bandages has different characteristic depending on material used, so the compression obtained the different result (Partsch, 2008).

Based on compression material standardized by British standard, elastic bandage can be classified into 3, which are: (Partch, 2008)

\section{a) Type 1 (Conforming/ Retension Bandage)}

This type serves as the resistant bandage with compression helping. This type contains light elastomeric thread with high elasticity.

b) Type 2 (Light Support)

This type is also known as minimal stretch bandage or short stretch bandage. It is made of cotton and viscose (nabati composition). This kind of bandage is used to use to prevent edema and it is usually used for mild sprain. If it is compared to type 3 , this bandage will have stretch power and limited elasticity. This bandage is used to use venous ulcer treatment. The character of this bandage is it will not be elastic anymore because the maximum stretching occurs. Thus, it tends to restrain the geometry's changing caused by calf muscle contraction during walking. The special characteristic of this short stretch bandage is giving high working pressure when the under muscle has contraction, however giving low resting pressure when the muscle rest will not give tourniquet effect. Because of having limited elasticity, this bandage is less effective than compression bandage when decreasing edema. The elasticity of the bandage is less than $60 \%$. The example of this bandage is like Elastocrepe $\AA$, Leukocrepe $囚$.

c) Type 3 (Compression Bandage)

The use of this compression is to provide the pressure which is normally used to control edema and reduce the swelling which is caused by venous disorder. Long stretch bandage is usually included in this classification because it can create higher pressure. The elasticity of this bandage can be as high as $140 \%$, like $A c e^{\mathrm{TM}}$, Elodur $\AA$. This type can be classified into 4 types as in the Table 1.

However, there are some different arguments about elastic bandage classifycation, it is because the pressure produced by a subject depending on the tension applied which compared to its constituent material (Partsch, 2008).

Each of elastic bandage which was applied in America consensus had been agreed about the usage which the characteristic is overlap with 2 minimum layers (Partsch, 2008).

Applying elastic bandage by spiral way with $50 \%$ overlap method was assumed that each round obtained effective pressure in the limb (Thomas, 2007). 
Indonesian Journal of Medicine (2017), 2(3): 146-153

https://doi.org/10.26911/theijmed.2017.02.03.01

Table 1. Compression bandage classification

\begin{tabular}{ccl}
\hline No. & \multicolumn{1}{c}{ Compression Types } & \multicolumn{1}{c}{ Pressure } \\
\hline 1 & Type 3a : Mild compression & Low pressure up to 20 $\mathrm{mmHg}$ \\
2 & Type 3b : Medium compression & Medium pressure up to 30 $\mathrm{mmHg}$ \\
3 & Type 3c : High compression & Pressure up to 40 mmHg \\
4 & Type 3d : Extra high compression & Pressure more than $50 \mathrm{mmHg}$ \\
- pressure is measured in the wrist area & \\
- pressure is assumed by bandaging applied with spiral way 50\% overlap \\
\hline
\end{tabular}

Sumber: Partsch (2008).

\section{Leukocrepe ${ }^{\circledR}$}

Leukocrepe ${ }^{\circledR}$ is non-adhesive elastic bandage typically short stretch bandage which is produced by BSN medical. The elastic bandage is made of $100 \%$ cotton. This bandage can be utilized in some cases such as lymphedema. It also can be applied to skin graft treatment case, donor site wound treatment, varicose veins handling, and secondary bandage after moist wound dressing, and for the sprain case and strain (BSN medical, 2016)

\section{Medicrepe $\AA$}

Medicrepe ${ }^{\circledR}$ is non-adhesive elastic bandage produced by OneMed, and with the material composition $50 \%$ of cotton, $41 \%$ of polyamide, and $9 \%$ of polyurethrane. It is kind of long stretch bandage because this bandage contains of polyurethrane material. The elasticity of this bandage is more than $100 \%$ than the short stretch bandage. (OneMed, 2016).

\begin{tabular}{l}
\hline SUBJECTS AND METHOD \\
1. Study Design \\
This study was experimental quantitative \\
design by implementing post-test only.
\end{tabular}

\section{Population and Sampel}

The population was collected from the entire patient who had been through intermediate STSG surgery in the thighs with 0.018 inches of thickness at RSUD Dr. Moewardi Surakarta.

The study was conducted in December 2017 - July 2017. The sample used hypothesis test formula on the average of the population. The study implemented Rule of Thumb theory with the total subject of the study was 30 patients. There were 18 patients as a substitute if the subject dropped out.

The sample was taken by applying purposive sampling technique which it included each of the patients who met the criteria of this study in certain time.

\section{RESULTS}

The description of research's data included gender, age, and epithelialization. The result of the 18 patients who were done intermediate STSG donor surgery can be drawn through this table below:

Table 2. Description of study's data

\begin{tabular}{lcccc}
\hline \multicolumn{1}{c}{ Characteristic } & $\mathrm{n}(\%)$ & Mean \pm SD & Minimum & Maximum \\
\hline Gender & & & \\
$\quad$ Female & $2(11.1 \%)$ & & & \\
$\quad$ Male & $16(88.9 \%)$ & & 4 & 86 \\
Age (year) & & $41.06 \pm 24.64$ & & \\
Epihelialization (\%) & & $61.39 \pm 30.05$ & 18.5 & 98 \\
$\quad$ Medicrepe & & $43.67 \pm 30.69$ & 5.6 & 90 \\
$\quad$ Leukocrepe & & & & \\
\hline
\end{tabular}


Table 3. Epithelial rate difference on donor wound split thickness skin graft in

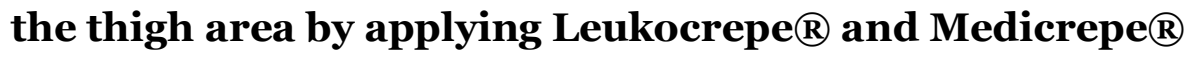

\begin{tabular}{lccc}
\hline Epithelialization (\%) & Mean & $\mathbf{Z}$ & $\mathbf{p}$ \\
\hline Medicrepe & $61.39 \pm 30.05$ & -3.508 & $<0.001$ \\
Leukocrepe & $43.67 \pm 30.69$ & & \\
\hline
\end{tabular}

The study applied Wilcoxon rank test to investigate the difference result between applying Leukocrepe $\AA$ and Medicrepe $\AA$ to the donor wound STSG in the thigh area.

It could be seen through the table 3 with the result $\mathrm{p}>0.05$ which meant there was a significant difference of the epithelial

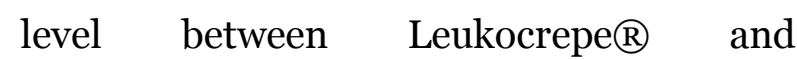
Medicrepe $\AA$ on the donor wound STSG in the thigh area. As we can see, mean score of

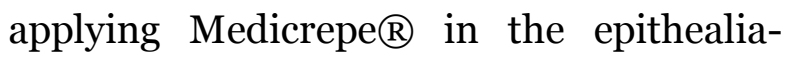
lization was $61.39+30.05 \%$, meanwhile the mean score of applying Leukocrepe $\AA$ was $43.67+30.69 \%$.

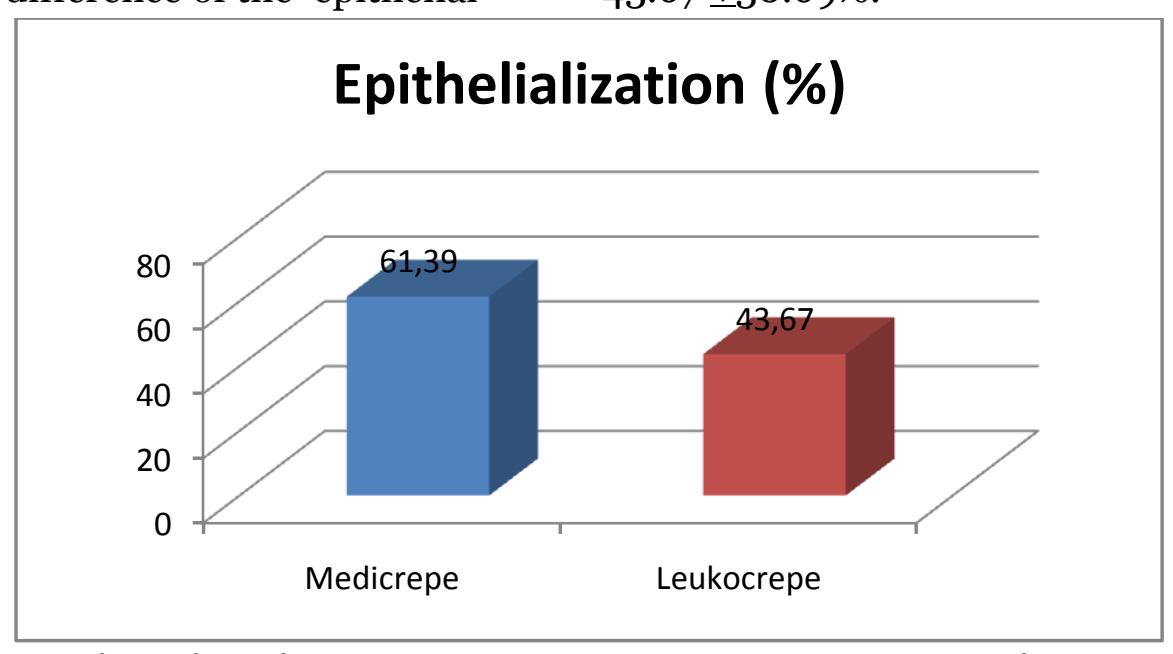

\section{Picture1. Epithelial difference on the donor wound STSG in the thigh area between applying Leukocrepe $\AA$ and Medicrepe $\AA$.}

The Picture 1 above described that epithelial level by applying Medicrepe $\AA$ was higher than Leukocrepe $\mathbb{R}$

\begin{tabular}{l}
\hline DISCUSSION \\
The result showed that there was a \\
significant difference result on the \\
epithelial level between applying Leuko- \\
crepe $\AA$ and Medicrepe $\AA$ on the STSG \\
donor wound in the thighs area. As we can \\
see from the result, it could be described \\
that the mean score of Medicrepe $\AA$ was \\
$61.39 \pm 30.05 \%$, meanwhile the mean score \\
of Leukocrepe $\AA$ was $43.67 \pm 30.69 \%$. \\
Through the study, applying \\
Medicrepe $\AA$ yielded better result. It was
\end{tabular}

because the elasticity of the bandage which could reach more than $100 \%$. Therefore, it could reach higher compression, increasing hydrostatic pressure and reabsorption. Moreover, the first phase of donor wound recovery is wet phase within 3-4 days in the first day. By controlling exudate process applying Medicrepe $\AA$, infection process was suppressed so the re-epithelialization process occurred more quickly.

According to the result conducted to 18 patients who have conducted intermediate STSG in the thigh area with 0.018 inches thickness at RSDM Surakarta. It could be concluded that on the seventh day of evaluation, the mean score of applying Medicrepe was $61.39 \pm 30.05 \%$, while 
Leukocrepe was $43.67 \pm 30.69 \%$. The statistic test's result showed that there was a significant difference between Medicrepe $(\AA$

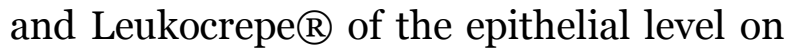
the donor wound STSG in the thigh area.

1. Donor wound STSG treatment was suggested to use elastic bandage

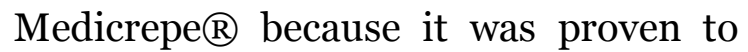
increase epithelial rate.

2. For the future researcher, to conduct research about STSG donor wound of epithelialization through histological assessment to minimize the subjectivity study level.

\begin{tabular}{l}
\hline \multicolumn{1}{c}{ REFERENCES } \\
\hline Atiyeh BS (2002). Improved Healing of \\
Split Thickness Skin Graft Donor \\
Sites. The Journal of Applied Re- \\
search. 2: 6-9.
\end{tabular}

Beldon P (2007). Procedure and management of skin grafts in the community. Br J community Nurs. 8(6): 8-18.

Bhagwat AM, Save S, Burli S, Karki SG (2001). A Study to Evaluate the Antimicrobial Activity of Feracrylum and Its Comparison with Povidone-Iodine. Indian J. Pathol. Microbial. 44(4): 431-433.

Bindl C (2011). Bandage Stabilizer. Diunduh dari http://bmeddeign.engr.wisc.edu/projects/file/?fid $=1788$ pada 1 oktober 2016.

Bloemen (2012). Digital image analysis versus clinical assessment of wound epithelialization: a validation study; 501-505.

Brayn RA, Clark RA, Nix DP. 2007. Acute and chronic wounds. Current management concepts 3rd ed. St Louis, Mo: Mosby Inc: 100 29. http://www.ncbi.nlm.nih.gov/pubmed/10692634. 5 September 2016.
Casey AJ, Clark RAF (2011). Mechanisms of disease: Cutaneous wound healing. N Engl J Med. 341(10): 738-46.

Dale BA (2011). Wound CareDressing. Home Health care Nurse: 429-440.

Davies P (2007). Skin adhesives and their role in wound dressings. Wounds UK. 3(4): 76-86.

Gurtner GC, Thorme CH (2007). Wound healing: Normal and abnormal. Grabb and Smith's plastic surgery 6thed: Lippincot Williams \& Wilkins: 15-22.

Hatice O (2010). Effects of Three Types of Honey on Cutaneous Wound Healing. Wounds, 22(11): 275-283.

Helfman T (2014). Occlusive J Dressing and Wound Healing. Clinics in Dermatology. 12:121-127

Istiqomah (2010). Perbedaan Perawatan Luka Dengan Menggunakan Povodine Iodine 10\% Dan $\mathrm{NaCl}$ 0.9\% Terhadap Proses Penyembuhan Luka Pada Pasien Post Operasi Prostatektomi Di Ruang Anggrek RSUD Tugurejo Semarang. Semarang: Universitas Diponegoro.

Jackie (2014). Achieving effective outcomes in patients with overgranulation tissue. Wound care alliance UK; 1-10.

Khalid K (2008). Scalpasa Donor Site for Split Thickness Skin Grafts. J.Ayyub Med CollAbbottabad: 20

Lawrence WT (2012). Wound Healing Biology and Its Application to Wound Management: O'Leary P. The Physiologic Basis of Surgery. Edisi ke-3. Philadelphia: Lippincott Williams \& Wilkins; 107-32.

Lestari S (2008). Perawatan Post Operatif. Lokakarya dan Workshop Bedah Kulit Dasar. Universitas Andalas.

Lojpur M (2001). Dressing and bandage. 110 .

Nelson FMD (2008). Robbins and Pathologic Basis of diseases. Elsevier, 
philadelpia internasional edition 39(1): $77-84$

Partsch H (2003). Understanding the pathophysiological effects of compression. Understanding compression therapy. Medical education partnership. Smith and Nephew. 1-17

Partsch H (2008). Classification of Compression Bandage: Parctical Aspects. Dermatologic Surgery Article. Researchgate;600-607

Perdanakusuma DS (1998). Skin Grafting, Surabaya: Airlangga University Press, 1-38.

Ramona DL (2010). Skin Graft. Medan: Universitas Sumatera Utara. Di unduh dari www.repository.usu.ac.id/bitstream/123456789/3401/1/o8Eo 0894.pdf diakses (11 Januari 2016)

Schwart B, Neumeister M (2006) The Mechanism of Wound Healing. Future Direction in Surgery.

Shimizu R (2012). Review article: Skin Graft in Plastic Surgery International volume 2012. Di unduh dari http://www.hindawi.com/journals/psi/2012 /563493/ (5 september 2016)
Sjamsuhidajat R, Jong WD (2005). Luka dan Penyembuhan Luka. Buku Ajar Ilmu Bedah. Jakarta, ECX.

Sudjatmiko G (2007). Petunjuk Praktis Ilmu Bedah Plastik Rekonstruksi. Jakarta, Yayasan Khasanah Kebajikan.

Thomas S (2007). Compresion Bandaging in treatment of Venous Leg Ulcers. World Wide Wounds.

Weller C, Sussman G (2006). Wound dressing update. Journal of Pharmacy Practice and Research. 36 (4): 318-32.

White R (2006). Modern exudate management: a review of wound treatments. World wide wounds journal: 25-35.

Wiechula R (2011). Post Harvest Management of split Thickness Skin Graft Donor Sites. A Systemic Review No. 13, The Joanna Briggs Institute, Adelaide.

Zuther JE, Norton S (2012). Lymphedema Management: The Comprehensive Guide for Practitioners. 2nd ed. New York, NY: Thieme. 